\title{
Antidiabetic activity and phytochemical screening of extracts of the leaves of Ajuga remota Benth on alloxan-induced diabetic mice
}

Tadesse Bekele Tafesse ${ }^{1 *}$, Ariaya Hymete ${ }^{2}$, Yalemtsehay Mekonnen ${ }^{3}$ and Mekuria Tadesse ${ }^{4}$

\begin{abstract}
Background: Ajuga remota Benth is traditionally used in Ethiopia for the management of diabetes mellitus. Since this claim has not been investigated scientifically, the aim of this study was to evaluate the antidiabetic effect and phytochemical screening of the aqueous and $70 \%$ ethanol extracts on alloxan-induced diabetic mice.

Methods: After acute toxicity test, the Swiss albino mice were induced with alloxan to get experimental diabetes animals. The fasting mean blood glucose level before and after treatment for two weeks in normal, diabetic untreated and diabetic mice treated with aqueous and $70 \%$ ethanol extracts were performed. Data were statistically evaluated by using Statistical Package for the Social Sciences software version 20. P-value $<0.05$ was considered statistically significant.

Results: The medium lethal doses $\left(\mathrm{LD}_{50}\right)$ of both extracts were higher than $5000 \mathrm{mg} / \mathrm{kg}$, indicating the extracts are not toxic under the observable condition. Aqueous extracts of A.remota (300 mg/kg and $500 \mathrm{mg} / \mathrm{kg}$ body weight) reduced elevated blood glucose levels by $27.83 \pm 2.96 \%$ and $38.98 \pm 0.67 \%(P<0.0001)$, respectively while the $70 \%$ ethanol extract caused a reduction of $27.94 \pm 1.92 \%(300 \mathrm{mg} / \mathrm{kg}) \& 28.26 \pm 1.82 \%(500 \mathrm{mg} / \mathrm{kg})$. Treatment with the antidiabetic drug, Glibenclamide (10 mg/kg body weight) lowered blood glucose level by $51.06 \%(p<0.05)$. Phytochemical screening of both extracts indicated the presence of phenolic compounds, flavonoids, saponins, tannins, and steroids, which might contribute to the antidiabetic activity. The extracts, however, did not contain alkaloids and anthraquinones.
\end{abstract}

Conclusion: The aqueous extract $(500 \mathrm{mg} / \mathrm{kg}$ ) showed the highest percentage reduction in blood glucose levels and the ability of $A$. remota extracts in reducing blood glucose levels presumably due to the presence of antioxidant constituents such as flavonoids. The effect of the extract supported the traditional claim of the plant.

Keywords: Ajuga Remota, Antidiabetic activity, Blood glucose level, Diabetes mellitus, Glibenclamide, Phytochemical screening

\footnotetext{
* Correspondence: tadie2007@yahoo.com

${ }^{1}$ School of Pharmacy, College of Health \& Medical Sciences, Haramaya

University, Harar, Ethiopia

Full list of author information is available at the end of the article
} International License (http://creativecommons.org/licenses/by/4.0/), which permits unrestricted use, distribution, and reproduction in any medium, provided you give appropriate credit to the original author(s) and the source, provide a link to the Creative Commons license, and indicate if changes were made. The Creative Commons Public Domain Dedication waiver (http://creativecommons.org/publicdomain/zero/1.0/) applies to the data made available in this article, unless otherwise stated. 


\section{Background}

Diabetes mellitus, one of the major public health problems worldwide, is a metabolic disorder of multiple etiologies distinguished by a failure of glucose homeostasis with disturbances of carbohydrate, fat and protein metabolism as a result of defects in insulin secretion and/or insulin action [1, 2]. According to International Diabetes Federation (IDF) report, elevated blood glucose is the third uppermost risk factor for premature mortality, following high blood pressure and tobacco use globally [2].

Cardiovascular diseases, neuropathy, nephropathy, and retinopathy are among the major risks that are associated with diabetes. These chronic complications may lead to hardening and narrowing of arteries (atherosclerosis) that could advance to stroke, coronary heart disease, and other blood vessel diseases, nerve damage, kidney failure, and blindness with time [3].

In 2015, according to IDF report, 415 million (8.8\%) adults (aged 20-79) worldwide were estimated to have diabetes; this number is expected to rise to 642 million (10.4\%) by 2040 or one adult in ten people. An estimated 14.2 million adults aged 20-79 had diabetes in the Africa Region that represents a regional prevalence of $3.2 \%(2.1-6.7 \%)$ in 2015 , which can be projected to $3.7 \%(2.6-7.3 \%$; 34.2 million) by 2040 . South Africa (2.3 million), Democratic Republic of Congo (1.8 million), Nigeria (1.6 million) and Ethiopia (1.3 million) are among the highly populated African countries containing the highest number of people living with diabetes [2].

In Ethiopia, even though the occurrence of diabetes has not been made nationally, hospital-based studies indicate that its prevalence has increased from $3.32 \%$ in 2012 [4] to $3.4 \%$ in 2015 and the number of diabetic cases is expected to increase to 10.6 million by 2040 [2].

Diabetes mellitus can be managed by diet, physical exercise, and modern drugs (insulin and/or oral hypoglycemic drugs such as sulfonylureas and biguanides) [5]. Different extracts from medicinal plants have also been used traditionally to manage diabetes globally, and these are considered as relatively inexpensive, less toxic and with relatively little or no side effects [6]. There are also medicinal plants that contain some toxic constituents such as the cytotoxic anti-cancer plantderived drugs, digitalis; however, the side effects of the phytotherapeutic agents are less common compared with synthetic drugs [7]. Management of diabetes without any side effect is still a challenge and the available modern antidiabetic agents produce serious side effects such as hypoglycemia (Sulphonylureas), lactic acidosis and folate and B12 malabsorption (Metformin), gastrointestinal symptom (Acarbose), weight gain (Sulphonylureas and Thiazolidinediones), and edema (Thiazolidinediones) [8]. Hence, the search for safer and more effective hypoglycemic agents has continued.
Globally, medicinal plants have been used as a source of medicine and $80-85 \%$ of populations rely on these medicinal plants using the extracts or their active components as traditional medicine to meet their primary health care needs $[9,10]$. A number of active components were isolated from medicinal plants for direct use as drugs, or act as a lead compound or pharmacological agents. Metformin, for example, is an oral hypoglycemic agent isolated from medicinal plant Galega officinalis that was used historically in medieval Europe for the treatment of diabetes [11-13].

Ajuga remota Benth (synonyms: Ajuga integrifolia Buch.-Ham, Ajuga bracteosa Wall ex Benth.) [14], is a shrub in the Lamiaceae family that grows widely in East Africa, at an altitude of $1500-3400 \mathrm{~m}$ above sea level in Saudi Arabia, Yemen and Afghanistan to East Asia $[15,16]$. In the Ethiopian traditional health system, A.remota is commonly used for the treatment of various diseases including diabetes, malaria, toothache, skin disease, high blood pressure, stomach pain, pneumonia, liver problem and swelling of legs. Due to the bitter taste of the extract, sometimes honey is added to the preparation so as to make it palatable and for longer period storage for later use. In Ethiopia, the vernacular names for A.remota include 'Harmagussa' (Ormigna), 'Akorarach' (Amharic); 'Etse-Libawit' (Ge'ez), 'Akembiye' (Guragegna), and 'Tale' (Welaytigna) [15-20].

The plants of the genus Ajuga have been assessed for different activities such as antiviral activity against Human Immunodeficiency Virus type 1 (HIV-1) and Type 2 (HIV-2) [21], antipyretic [22], diuretic [23], anti-inflammatory, antidepressant, anticoagulant [24], analgesic [24, 25], antiarthritic [26], antifeedant, antifungal, antihypertensive, insecticidal $[18,27,28]$, antimicrobial [29], antioxidant [24, 29, 30], hypoglycemic [31-35], antinociceptive [36], hypolipidemic [37], antimycobacterial [38], and antimalarial/antiplasmodial activities [18, 19, 27, 28, 39, 40].

To verify the traditional uses of the plant Ajuga genus, various in vitro and in vivo studies have been conducted on different extracts of the species of the genus Ajuga using animal models, such as mice or rats; as their genetic, biological and behavior characteristics closely resemble human beings. A.remota, A.bracteosa, A.integrifolia, and A.iva are some of the species of the genus Ajuga that are ecologically related and were evaluated for various pharmacological applications.

Different extracts of A.bracteosa wall ex. Benth was evaluated for its analgesic effect using Swiss albino mice with acetic acid-induced writhing and tail immersion test. A dose-dependent analgesic effect was observed at 200 and $400 \mathrm{mg} / \mathrm{kg}$ from the water and chloroform extracts [25]. In another study that used A.bracteosa Wall ex Benth, its antiarthritic effect was evaluated in albino 
rats using a $70 \%$ ethanolic extract and dose-dependent activities with a better effect than that of aspirin was observed after six $h$ treatment on acute nonimmunological arthritis and complete Freund's adjuvant (CFA)-induced chronic immunological arthritis. The antiarthritic effect was reported to be due to the presence of the active constituents' ajugarin I, lupulin A, withaferin $\mathrm{A}$, reptoside and 6-deoxyharpagide that were isolated from the plant [26].

In Taiwan, in vitro and in vivo hypoglycemic effect was evaluated on the $70 \%$ ethanol extracts of five Ajuga species namely; A.decumbens, A.nipponensis, A.pygmaea, A.taiwanensis and A.dictyocarpa on streptozotocininduced diabetic mice. Among them, A.nipponensis showed a superior effect in $\alpha$-glucosidase inhibition $(28.62 \pm 1.56 \%)$ and glucose uptake $(54.15 \pm 2.56 \%)$ and somewhat postprandial blood glucose levels reduction. It also contains the highest content of flavonoids and ecdysterone as compared with the other species [32].

A phytoecdysteroids rich aqueous extract from A.iva on alloxan-induced diabetic rats significantly $(p<0.01)$ decreased the level of blood glucose level and increased hepatic glycogen levels [34]. In another study, the aqueous extract of whole parts of A.iva was examined for hypolipidemic and hypoglycemic effect on streptozotocininduced diabetic rats and a significant reduction in plasma cholesterol and triglyceride levels were observed by $35 \%$ $(P<0.01)$ and $13 \%(P<0.05)[35]$ and $44 \%(P<0.01)$ and $30 \%(P<0.01)$ [37], respectively while the plasma levels of glucose was reduced by $24 \%(P<0.05)$ [35].

A.remota and the other species of the genus Ajuga have a number of common phytochemical compounds. Although ample ethnobotanical, in vitro and in vivo evidence exists for the use of Ajuga species in the management of diabetes, the claim of A.remota has not been substantiated scientifically. Therefore, the aim of this study was to find out the scientific basis of the use A.remota in the management of diabetes used by traditional practitioners using aqueous and $70 \%$ ethanol extracts on alloxan-induced diabetic mice.

\section{Methods}

\section{Collection of plant material}

The leaves of Ajuga remota Benth were collected from Lebu, a few kilometers Southwest of Addis Ababa, Ethiopia in January 2008. Taxonomic identification was made by Mr. Melaku Wondafrash at the National Herbarium, College of Natural Sciences, Addis Ababa University and a voucher specimen (Voucher Specimen number T001) was preserved.

\section{Chemicals and instruments}

Alloxan monohydrate (Sigma Chemical Company, USA) was used to induce diabetes in mice and Glibenclamide
(Hoechst Pharmaceuticals, Mumbai) was used as a standard hypoglycemic drug. Ethanol (BDH Ltd., England) and distilled water were used for extraction of the plant materials. ACCU CHEK Performa Glucometer (Roche Diagnostics India Pvt. Ltd., India) was used to measure the blood glucose level. For evaporating the solvents, BUCHI Rotavapour R-200, Switzerland and Lyophilizer (freeze dryer) (type: Heto power dry LL3000 Wag tech) was used. The following chemicals were used for phytochemical screening test: Chloroform and Ethyl acetate (ACS, Merck); Hydrochloric acid, Ferric sulphate, Lead acetate and Potassium ferrocyanide (BDH Ltd., England); Petroleum ether $60-80{ }^{\circ} \mathrm{C}$ (Labmerk Chemicals LTD India); Sulphuric acid (Farm Italia Carrloerba, Italy); Acetic anhydride and Methanol HPLC grade (Techno Pharmchem, Bahadurgarm, India); n-Hexane (Rathburn Chemicals Ltd., England); Acetonitrile (Sigma Aldrich, Germany) and Ferric chloride (FISHER Scientific Company, USA). All the chemicals were of analytical grades.

\section{Experimental animals}

Adult male Swiss albino mice bred in the animal house of Ethiopian Health and Nutrition Research Institute, Addis Ababa, Ethiopia, with weights ranging from 24 to $35 \mathrm{~g}$ and eight weeks of age were used for the experiment. The animals were kept in cages made of polypropylene ( 5 mice per cage randomly) at $23 \pm 2{ }^{\circ} \mathrm{C}$ with $12 \mathrm{~h} / 12 \mathrm{~h}$ light/dark cycle [41-44]. Standard pellet and water were allowed to the animals throughout the experiment, except the fasting period. The care and handling of animals were in accordance with internationally accepted ethical guidelines for use of laboratory animals [44] and the study protocol was approved by the School of Pharmacy Ethics Committee, Addis Ababa University, Ethiopia.

\section{Extraction of plant material}

The leaves of A.remota were air-dried for one week under the shade at room temperature at Essential Oils Research Center laboratory, Addis Ababa. The dried plant material was manually powdered finely and used for extraction.

\section{$70 \%$ ethanol extract}

One hundred gram of the dried and powdered leaves of A.remota was kept in a thimble and extracted with $70 \%$ ethanol in a Soxhlet extractor. The extraction process was continued until the color of the final drop of the extract became colorless. Then, ethanol was removed from the extract using a rotavapor (BUCHI Rotavapor R-200, Switzerland) at $60{ }^{\circ} \mathrm{C}$ and the remaining $30 \%$ water was removed using Lyophilizer (freeze dryer) (type: Heto power dry LL3000 Wag tech). The resulting dry 
hydroalcoholic extract has a percentage yield of $10.95 \%$ $(w / w)$. The extract was kept in a refrigerator until used for the experiment.

\section{Aqueous extract}

Twenty gram of the dried and powdered leaves of A.remota was added to $100 \mathrm{~mL}$ hot distilled water $\left(60^{\circ} \mathrm{c}\right)$, mixed thoroughly and heated for $20-30 \mathrm{~min}$. on a water bath with continuous stirring as traditionally done and cooled to room temperature. The decoction obtained was filtered under suction and Lyophilizer (freeze dryer) (type: Heto power dry LL3000 Wag tech) was used to dry the aqueous extract. The dried aqueous extract has $13.5 \%(w / w)$ percentage yield. The freezedried aqueous extract was kept in a refrigerator until used for the experiment and then the dried plant extract was reconstituted with distilled water for oral administration.

\section{Acute toxicity test}

Acute toxicity test were done on both plant extracts after the animals had been fasted overnight while only taking water [45]. The weight of each mouse was recorded before administering the extract. Randomly the animals were divided into a control and three treatment groups (separately for both extracts), each group consisting of five mice. The control group received only the vehicle (1\% Tween 80$)$ and each treatment group received orally the $70 \%$ ethanol and aqueous extracts of A.remota in a dose of 1000, 2000 and $5000 \mathrm{mg} / \mathrm{kg}$ [46]. Animals were kept under close observation for explicit toxicities and/or behavioral changes like restlessness, tremor, diarrhea, sluggishness, loss of weight, and paralysis at regular intervals for the first four $\mathrm{h}$ after administering the extract [47], and then they were observed daily for two weeks for any change in general behavior and/or other physical activities. Food was available after four $h$ of administration of the extracts.

\section{Induction of experimental diabetes}

Male Swiss albino mice were fasted overnight (12-14 h) and their weight and fasting blood glucose level recorded with a glucometer and then made diabetic by a single intraperitoneal injection (a volume of $1 \mathrm{~mL} / \mathrm{kg}$ ) of freshly prepared alloxan monohydrate solution $(20 \mathrm{mg} /$ $\mathrm{kg}$ body weight). Alloxan was prepared by weighing according to individual animal weight and solubilized with $0.5 \mathrm{~mL}$ sodium citrate at $\mathrm{pH} 4.5$ before injection. Food and water were presented to the animals $30 \mathrm{~min}$. after administration of alloxan [48, 49]. After $48 \mathrm{~h}$ of alloxan injection, plasma blood glucose level of each animal was determined by taking the blood from the tail and animals with a fasting blood glucose level above $200 \mathrm{mg} / \mathrm{dL}$ $[50,51]$ were included in the study.

\section{Experimental design}

The animals were divided into seven groups for the evaluation of fasting blood glucose level and oral glucose tolerance test with five animals in each group. They were treated with the plant extracts two days after alloxan injection excluding the diabetic control groups. Blood samples were drawn for measuring blood glucose levels from each group on day 1, 7 and 14 during the study period [43]. Changes in body weight were also recorded. Groups 1 and 2 served as normal and diabetic controls (receiving only the vehicle, i.e. $1 \%$ Tween 80 ), respectively. Group 3 received standard drug (glibenclamide, $10 \mathrm{mg} / \mathrm{kg}$ per day orally) [45]. Groups 4 \& 5 received the $70 \%$ ethanol extract at a dose of $300 \& 500 \mathrm{mg} / \mathrm{kg}$, respectively and groups $6 \& 7$ received aqueous extract at a dose of $300 \& 500 \mathrm{mg} / \mathrm{kg}$, respectively daily in one $\mathrm{mL}$ aqueous solution using oral gavage for two weeks.

\section{Oral glucose tolerance test}

After two weeks of treatment with the plant extracts, the animals were made to fast for $12-14 \mathrm{~h}$ but had free access of water and their fasting blood glucose level was measured four times. Glucose solution $(2 \mathrm{~g} / \mathrm{kg}$ of body weight) was administered orally in a volume of $1 \mathrm{~mL} / \mathrm{kg}$. Blood samples were collected at the time interval of 30 , 60 and $120 \mathrm{~min}$. after administration of glucose [41].

\section{Phytochemical screening}

Preliminary phytochemical screening of the plant extracts was carried out using standard procedures [52], to check for the presence or absence of secondary metabolites such as alkaloids, steroidal compounds, phenolic compounds, flavonoids, saponins, tannins and anthraquinones.

\section{Statistical analysis}

Data are expressed as a mean \pm standard deviation. Differences among treatment group means were assessed by two-way analysis of variance (ANOVA) and group means were considered to be significantly different at $P<0.05$. Data were statistically evaluated using Statistical Package for the Social Sciences (SPSS) version 20.0 software. Bar and line charts were drawn using Excel 2007 software.

\section{Results and discussion} Acute toxicity test

The acute toxicity study showed that the administration of graded doses of both the aqueous and 70\% ethanol extracts of A.remota did not generate any observable signs of toxicity up to the dose of $5000 \mathrm{mg} / \mathrm{kg}$, which is consistent with Debela et al., 2005 [22] and Hailu and Engidawork, 2014 reports [23]. This was confirmed by the absence of significant changes in behaviours such as 
alertness, motor activity, weight loss, sluggishness, paralysis, breathing, restlessness, diarrhoea, convulsions, and coma. In addition, no death was observed for two weeks and they were physically active. The result proves that the plant extracts had no observable adverse effect at the doses tested; implying that the medium lethal dose $\left(\mathrm{LD}_{50}\right)$ is greater than $5000 \mathrm{mg} / \mathrm{kg}$ body weight in mice. Since its actual median lethal dose (LD50) is greater than $5000 \mathrm{mg} / \mathrm{Kg}$, extract of A.remota is nontoxic [53].

\section{Effect of $A$. remota leaves extract on fasting blood glucose level}

Alloxan-induced diabetic mice were treated with aqueous and $70 \%$ ethanol extracts of A.remota, once a day orally, for 14 days. The effect of different doses of the extracts of A.remota on fasting blood glucose level is presented in Fig. 1. The present study was intended to examine the antidiabetic effects of the extracts of $A$. remota leaves. The dose of $A$. remota (300 and $500 \mathrm{mg} /$ $\mathrm{kg}$ body weight) was selected based on previous studies in the Ajuga species [32, 36].

Alloxan monohydrate has been used to induce diabetes mellitus in experimental mice $[48,49]$. A single intraperitoneal administration of $20 \mathrm{mg} / \mathrm{kg}$ body weight alloxan monohydrate solution induced effectively diabetes mellitus in mice. This was confirmed by elevated level of fasting blood glucose that can be obtained from the tail of the mice after $48 \mathrm{~h}$ of injection.
Alloxan brings diabetes through selective destruction of insulin secreting pancreatic $\beta$-cells due to its accumulation through the glucose transporter 2 (GLUT2) and hence, minimize the glucose uptake by peripheral tissues. It is known that alloxan induces free radical formation by redox reactions that cause tissue injury and make $ß$-cells to degranulate and consequently degenerate $[48,54]$.

As expected in the diabetic control there was a $9.1 \% \pm 1.5$ increases in mean blood glucose level and significant difference $(p<0.0001)$ with the normal control mice. The blood glucose level of diabetic mice was estimated before and after 1st, 7th and 14th days of treatment. Both the aqueous and $70 \%$ ethanol $A$. remota extract treatment groups show a statistically significant difference with normal and diabetic control mice with $p<0.0001$. There is also a statistical significant difference between each dose of aqueous extracts $(P<0.005)$ and the $70 \%$ ethanol extract $(300 \mathrm{mg} / \mathrm{kg})(P<0.0001)$. However, there were no significant differences $(P>0.05)$ among the $70 \%$ ethanol extract with $500 \mathrm{mg} / \mathrm{kg}$ (AE500) and both aqueous extracts and Glibenclamide.

The average percentage of decrease in blood glucose levels (Table 1) showed an increase in the percentage with a relative increasing dose administration of $A$. remota extracts. However, the aqueous extract of $A$. remota with dose of $500 \mathrm{mg} / \mathrm{kg}$ body weight had a greater percentage decrease $(38.98 \pm 0.67)$ than any of the extracts after 14 days of treatment administration. Glibenclamide (10 $\mathrm{mg} / \mathrm{kg}$ body weight) treated diabetic

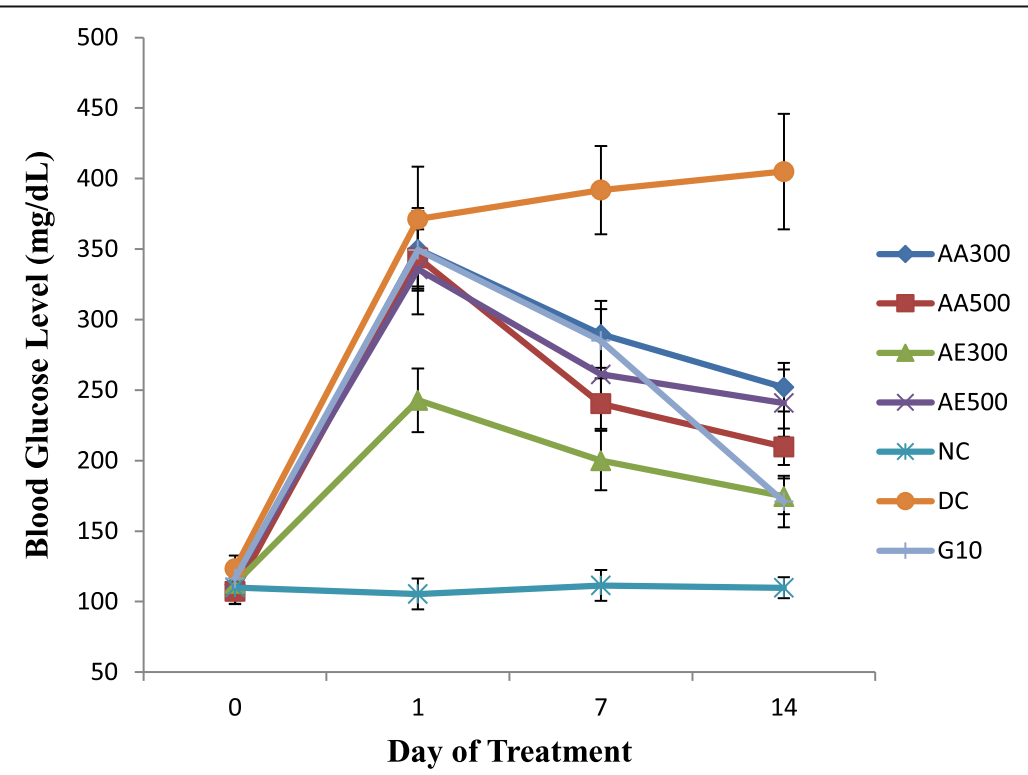

Fig. 1 Effect of extracts of A.remota on fasting blood glucose level in normal control and alloxan-induced diabetes mice. AA300: Aqueous Extract of A.remota (300 mg/kg per day); AA500: Aqueous Extract of A.remota (500 mg/kg per day); AE300: 70\% Ethanol Extract of A.remota (300 mg/kg per day); AE500: 70\% Ethanol Extract A.remota (500 mg/kg per day), NC: Normal Control; DC: Diabetic Control; G10: Glibenclamide (10 mg/kg per day). Data was expressed as mean \pm SD $(n=5)$ 
Table 1 Average Percentage Decrease of Blood Glucose Level (\% DBGL)

\begin{tabular}{ll}
\hline Group of Treatments & DBGL (\%) \\
\hline $\begin{array}{l}\text { Diabetic + Aqueous A. remota Extract } \\
\text { (300 mg/kg body weight) }\end{array}$ & $27.83 \pm 2.96$ \\
$\begin{array}{l}\text { Diabetic + Aqueous A. remota Extract } \\
\text { ( } 500 \mathrm{mg} / \mathrm{kg} \text { body weight) }\end{array}$ & $38.98 \pm 0.67$ \\
$\begin{array}{l}\text { Diabetic }+70 \% \text { Ethanol A. remota Extract } \\
\text { (300 mg/kg body weight) }\end{array}$ & $27.94 \pm 1.92$ \\
$\begin{array}{l}\text { Diabetic }+70 \% \text { Ethanol A. remota Extract } \\
\text { (500 mg/kg body weight) }\end{array}$ & $28.26 \pm 1.82$ \\
Diabetic + Glibenclamide ( $10 \mathrm{mg} / \mathrm{kg}$ body weight) & $51.10 \pm 2.95$ \\
\hline
\end{tabular}

mice showed a $51.10 \pm 2.95$ percentage reductions as positive control.

The extracts of $A$. remota leaves reduced elevated fasting blood glucose level. The mechanism of antidiabetic effects of the extracts of $A$. remota leaves might be due to presence of well-known antioxidant phytochemicals like flavonoids, polyphenols, and tannins, which acts as a free radical scavengers $[54,55]$. The presumed mechanism of action of these antioxidants was because of an insulin mimetic effect on the peripheral tissues by either stimulation of regeneration process or release of pancreatic secretion of insulin from existing $\beta$-cells. On top of this mechanism; there are also other mechanisms that play a great role in the reduction of blood glucose levels as potential antidiabetic plants. Increasing the speed of the release of glucose from the circulation by accelerating filtration and renal excretion and increasing the release of glucose through enhanced metabolism or integrate into fat deposits, a process relating to the pancreas to produce insulin are among the others [54].

A significant number of compounds have been isolated from various species of the Ajuga herb including; sterols (ajugalactone, $\beta$-sitosterol, $\gamma$-sitosterol, stigmasterol,), phenolic components, arabinose, cerotic acid, ecdysterone, phytoecdysteroids (phytoecdysteroid, Cyasterone, ajugalactone, ajugasterone A-C), flavonol glycosides, triterpenoid (ergosterol-5,8-endoperoxide), iridoid glycoside (8-O-acetylharpagide, 6,8-diacetylharpagide, Ajureptoside, 8-acetylherpagide, Herpagide,), neoclerodanediterpenes and diterpenes (ajugarins I, II, IV and V) $[16,19,28,38,56-58]$.

The result of this research supported the traditional use of the plant extract for the management of diabetes as claimed by traditional practitioners in Ethiopia. However, we are not certain about the mechanism of the antidiabetic action of the extracts. Therefore, further investigation needs to be performed.

\section{Oral glucose tolerance test}

The mean blood glucose levels of normal (negative control), diabetic mice untreated (positive control) and diabetic mice treated with A.remota extracts that were subjected to glucose tolerance test after two weeks is presented in Fig. 2. The animals in each group $(n=5)$ fasted $12-14 \mathrm{~h}$ and then the fasting mean blood glucose level was evaluated after oral administration of glucose ( $2 \mathrm{~g} / \mathrm{kg}$ body weight) as a baseline. The mean blood glucose level in the normal control mice rise to a peak value after $60 \mathrm{~min}$ glucose load and decreased to near normal level after $120 \mathrm{~min}$. In diabetic control mice, however, the value increased to a peak after $60 \mathrm{~min}$ of glucose load and remained high over the next $60 \mathrm{~min}$, which is expected.

The animals that were treated with the extracts showed a reduction in the mean blood glucose levels after $60 \mathrm{~min}$ of glucose loading. At $60 \mathrm{~min}$, the blood glucose level reached the maximum in both the aqueous

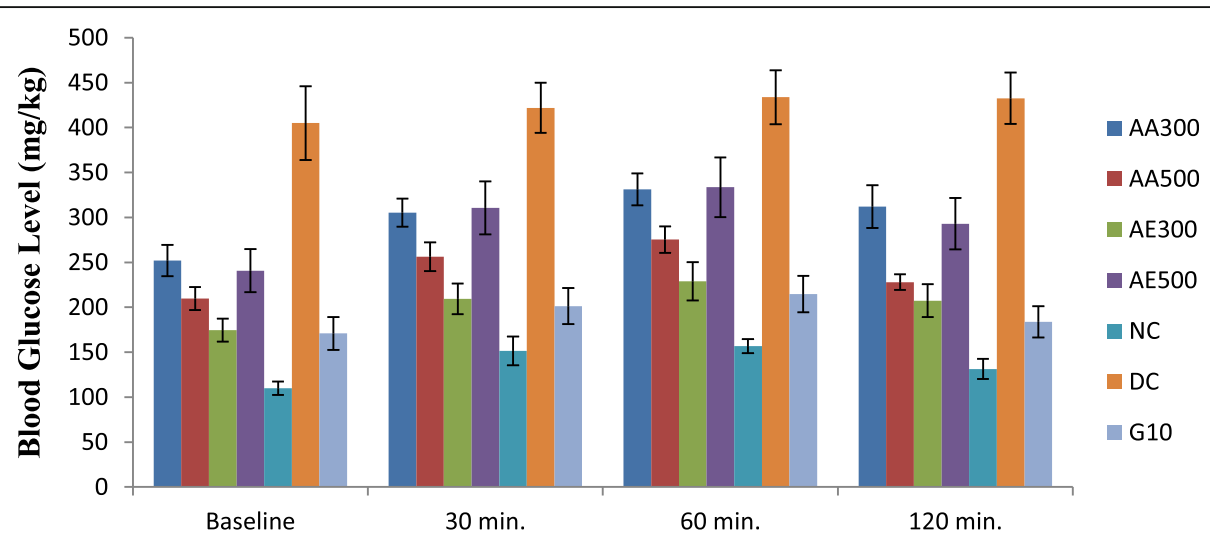

Time in min.

Fig. 2 Glucose tolerance test of A.remota extracts on alloxan-induced diabetic mice. AA300: Aqueous Extract of A.remota (300 mg/kg per day); AA500: Aqueous Extract of A.remota (500 mg/kg per day); AE300: 70\% Ethanol Extract of A.remota (300 mg/kg per day); AE500: 70\% Ethanol Extract A.remota (500 mg/kg per day), NC: Normal Control; DC: Diabetic Control; G10: Glibenclamide (10 mg/kg per day). Data was expressed as mean \pm SD $(n=5)$ 
and $70 \%$ ethanol extracts treated animals and then significant reduction was observed after $120 \mathrm{~min}$ of glucose administration. The aqueous extract at a dose of $500 \mathrm{mg} / \mathrm{kg}$ body weight showed a better reduction with $17.21 \%$ from the peak blood glucose level.

\section{Phytochemical screening}

Preliminary phytochemical screening was carried out using color forming and precipitating chemical reagents for detecting plant constituents from their extracts. The results obtained from the tests were summarized in Table 2, indicating the presence of flavonoids, tannins, saponins, phenolic compounds and steroids. This result was consistent with previous reports $[16,19,28]$. The extracts didn't contain alkaloids and anthraquinones. Epicatechin (flavonoids), catechin (tannin) and vindoline (an alkaloid) were some of the documented compounds that were isolated from the plant with a potential to decrease the blood glucose level [13, 42, 45]. Thus, the significant antidiabetic effect of the extracts of A.remota could be due to the presence of the abovementioned components in the extracts, which could act synergistically and/or independently to enhance the activity of glycolytic enzymes.

\section{Conclusion}

Oral administration of the extracts in doses from 1000 to $5000 \mathrm{mg} / \mathrm{kg} /$ day did not produce any significant changes in behaviors, indicating that the extracts are not

Table 2 Phytochemical screening of the aqueous extract of A. remota

\begin{tabular}{lll}
\hline Tests & Reagents & Inferences \\
\hline Alkaloids & Dragendorf's & - \\
& Mayer's & - \\
Anthraquinones & Test for free anthraquinones & - \\
& Test for o-anthraquinone glycosides & - \\
Flavonoids & $10 \%$ Lead acetate & + \\
& Sodium hydroxide & + \\
& Ethyl acetate & + \\
Phenolic & Ferric chloride and potassium & + \\
compounds & ferrocyanide & + \\
Saponins & Froth test & + \\
Steroidal & Acetic anhydride and conc. & + \\
& Sulfuric acid & + \\
Tannins & Chloroform and conc. Sulfuric acid & + \\
& Ferric chloride & + \\
& Aqueous hydrochloric acid & + \\
& Formaldehyde & Modified iron complex
\end{tabular}

Positive and negative symbol indicates the presence and absence of plant constituents, respectively. toxic under the observable condition in mice. The leaves of A.remota extracts had flavonoids, tannins, saponins, phenolic compounds and steroids, where some are considered as bioactive constituents in the management of diabetes. The A. remota extracts with each dose of 300 and $500 \mathrm{mg} / \mathrm{kg}$ body weight had antidiabetic effects on alloxan-induced Swiss albino mice. Percentage reduction in blood glucose levels of $A$. remota aqueous and $70 \%$ ethanol extract with dose of 300 and $500 \mathrm{mg} / \mathrm{kg}$ body weight each are $27.83 \pm 2.96$ and $38.98 \pm 0.67$ and $27.94 \pm 1.92$ and $28.26 \pm 1.82$, respectively. Hence, the chemical constituents of the plant extract might help in preventing diabetic complications and may serve as an alternative in the present armamentarium of antidiabetic drugs. Further study to substantiate the use of the plant as antidiabetic is recommended.

\section{Abbreviations}

AA300: Aqueous extract of Ajuga remota $300 \mathrm{mg} / \mathrm{kg} /$ day body weight; AA500: Aqueous extract of Ajuga remota $500 \mathrm{mg} / \mathrm{kg} /$ day body weight; AE300: Ethanol extract (70\%) of Ajuga remota $300 \mathrm{mg} / \mathrm{kg} /$ day body weight; AE500: Ethanol extract (70\%) of Ajuga remota $500 \mathrm{mg} / \mathrm{kg} /$ day body weight; DC: Diabetic Control; G10: Glibenclamide $10 \mathrm{mg} / \mathrm{kg} /$ day body weight; HIV-1/2: Human Immunodeficiency Virus type 1 and type 2; LD 50 :Medium Lethal Dose; NC: Normal control; SD:Standard Deviation

\section{Acknowledgements}

We would like to acknowledge Addis Ababa University, School of Graduate Studies, for supporting the project, Essential Oils Research Center for providing the chemicals, reagents and laboratory space during extraction, Department of Biology for providing animal house and Department of Chemistry, Addis Ababa University, for providing necessary chemicals. We also acknowledged colleagues and all those who assisted in conducting the study.

\section{Funding}

Not applicable.

\section{Availability of data and materials}

The plants were collected from Lebu, a few kilometers Southwest of Addis Ababa and Taxonomic identification was made by Mr. Melaku Wondafrash at the National Herbarium, College of Natural Sciences, Addis Ababa University, Ethiopia. A voucher specimen (Voucher Specimen number T001) was deposited in the National Herbarium of College of Natural Sciences, Addis Ababa, Ethiopia.

\section{Authors' contributions}

TBT, AH: Participated in developing the original idea and protocol. TBT, AH, YM, MT: All participated in laboratory work, data abstraction and analysis, preparing and editing the manuscript. All authors read and approved the final manuscript.

Competing interests

The authors declare that they have no competing interests.

Consent for publication

Not applicable.

\section{Ethics approval}

The care and handling of animals were in accordance with internationally accepted Ethical Guidelines for Laboratory animals, National Institutes of Health (NIH) Publication No. 86-23, Revised 1985 and the ARRIVE guidelines. The study protocol for laboratory animal use and care was approved by the Institutional Ethics Committee (Addis Ababa University, Addis Ababa, Ethiopia). 


\section{Publisher's Note}

Springer Nature remains neutral with regard to jurisdictional claims in published maps and institutional affiliations.

\begin{abstract}
Author details
${ }^{1}$ School of Pharmacy, College of Health \& Medical Sciences, Haramaya University, Harar, Ethiopia. ${ }^{2}$ School of Pharmacy, College of Health Sciences, Addis Ababa University, Addis Ababa, Ethiopia. ${ }^{3}$ Department of Biology, College of Natural Sciences, Addis Ababa University, Addis Ababa, Ethiopia. ${ }^{4}$ Ethiopian Institute of Agricultural Research, Addis Ababa, Ethiopia.
\end{abstract}

\section{Received: 16 December 2016 Accepted: 26 April 2017}

\section{Published online: 02 May 2017}

\section{References}

1. Barcelo A, Rajpathak S. Incidence and prevalence of diabetes mellitus in the Americas. Pan Am J Public Health. 2001:10(5):300-8.

2. International Diabetes Federation (IDF) Diabetes Atlas-7th Edition, 2015. http://www.diabetesatlas.org/resources/2015-atlas.html or (http://www. oedg.at/pdf/1606_IDF_Atlas_2015_UK.pdf).

3. Rubin R, Strayer DS, Rubin E. Rubin's Pathology: Clinicopathologic Foundations of Medicine, $6^{\text {th }}$ ed. Philadelphia: Lippincott Williams \& Wilkins, 2012; 1081-1098.

4. International Diabetes Federation (IDF) Diabetes Atlas-5 ${ }^{\text {th }}$ Edition, 2012 http://www.indiaenvironmentportal.org.in/files/file/diabetes\% 20atlas\%202012.pdf

5. Koski RR. Practical review of oral antihyperglycemic agents for type 2 diabetes mellitus. The Diabetes Educator. 2006;32(6):869-76.

6. Gupta R, Bajpai GK, Johri S, Saxena AM. An overview of Indian novel traditional medicinal plants with antidiabetic potentials. African Journal of Traditional, Complementary and Alternative Medicine. 2008;5(1):1-17.

7. Calixto JB. Efficacy, safety, quality control, marketing and regulatory guidelines for herbal medicines (phytotherapeutic agents). Braz J Med Biol Res. 2000;33:179-89.

8. Campbell I. Oral antidiabetic drugs: their properties and recommended use. Prescriber. 2007;18(6):56-74.

9. Ignacimuthu S, Ayyanar M, Sivaraman SK. Ethnobotanical investigations among tribes in Madurai district of Tamil Nadu (India). J Ethnobiol Ethnomed. 2006;2(25):1-7.

10. Elujoba AA, Odeleye OM, Ogunyemi CM. Traditional medicine development for medical and dental primary health care delivery system in Africa. African Journal of Traditional, Complementary and Alternative Medicines. 2005;2(1):46-61.

11. Li WL, Zheng HC, Bukuru J, De Kimpe N. Natural medicines used in the traditional Chinese medical system for therapy of diabetes mellitus. J Ethnopharmacol. 2004;92(1):1-21.

12. Fabricant DS, Farnsworth NR. The Value of Plants Used in Traditional Medicine for Drug Discovery. Environmental Health Perspectives, 2001; 109(Supl.1): 69-75.

13. Oubre AY, Carlson TJ, King SR, Reaven GM. From plant to patient: an ethnomedical approach to the identification of new drugs for the treatment of non-insulin dependent diabetes mellitus. Diabetologia. 1997;40(5):614-7.

14. Quattrocchi U. CRC world dictionary of medicinal and poisonous plants: common names, scientific names, eponyms, synonyms, and etymology. New York: CRC Press, Taylor \& Francis Group, Boca Raton, London; 2012. p. 137

15. Hedberg I, Kelbessa E, Edwards S, Demissew S, Persson E. Flora of Ethiopia and Eritrea. Plantaginaceae. The National Herbarium, Addis Ababa, Ethiopia, and Department of Systematic Botany, Uppsala. Sweden. 2006;5:527-8.

16. Coll J, Tandrón Y. Isolation and identification of neo-Clerodane diterpenes from Ajuga remota by high performance liquid chromatography. Phytochem Anal. 2005;16(1):61-7.

17. Abebe D, Debella A, Urga K. Illustrative checklist: medicinal plants and other useful plants of Ethiopia. Kenya: Ethiopian Health and Nutrition Research Institute (EHNRI), Camerapix Publisher International, Nairobi; 2003. p.188-194

18. Kuria, KA, De Coster S, Muriuki G, Masengo W, Kibwage I, Hoogmartens J, Laekeman GM. Antimalarial activity of Ajuga remota Benth (Labiatae) and Caesalpinia volkensii Harms (Caesalpiniaceae): in Vitro confirmation of ethnopharmacological use. Journal of Ethnophamacology, 2001; 74(2): 141-148.

19. Kuria KA, Chepkwony H, Govaerts C, Roets E, Busson R, De Witte P, Zupko I, Hoornaert G, Quirynen L, Maes L, Janssens L, Hoogmartens J, Laekeman G. Antiplasmodial activity of isolates of Ajuga remota. Journal of natural Product. 2002;65(5):789-93.
20. Ragunathan M, Abay SM. Ethnomedicinal survey of folk drugs used in Bahirdar Zuria district, northwestern Ethiopia. Indian J Tradit Knowl. 2009:8(2):281-4.

21. Asres K, Bucar F, Kartnig T, Witvrouw M, Pannecouque C, De Clercq E. Antiviral activity against human Immunodeficiency Virus type 1 (HIV-1) and type 2 (HIV-2) of ethnobotanically selected Ethiopian medicinal plants. Phytother Res. 2001;15(1):62-9.

22. Debela A, Makonnen E, Zerihun L, Abebe D, Teka F. In-vivo antipyretic studies of the aqueous and ethanol extracts of the leaves of Ajuga remota and Lippia adoensis. Ethiop Med J. 2005;43(2):111-8.

23. Hailu W, Engidawork E. Evaluation of the diuretic activity of the aqueous and $80 \%$ methanol extracts of Ajuga Remota Benth (Lamiaceae) leaves in mice. BMC Complement Altern Med. 2014;14(135):1-8.

24. Kayani WK, Dilshad E, Ahmed T, Ismail H, Mirza B. Evaluation of Ajuga Bracteosa for antioxidant, anti-inflammatory, analgesic, antidepressant and anticoagulant activities. BMC Complement Altern Med. 2016;16:375. do:10. 1186/s12906-016-1363-y.

25. Pal A, Pawar RS. A study on Ajuga bracteosa wall ex. Benth for analgesic activity. International Journal of Current Biological and Medical Science. 2011;1(2):12-4.

26. Kaithwas G, Gautam R, Jachak SM, Saklani A. Antiarthritic effects of Ajuga Bracteosa wall ex Benth. In acute and chronic models of arthritis in albino rats. Asian Pacific Journal of Tropical Biomedicine. 2012;2(3):185-8.

27. Muregi FW, Chhabra SC, Njagi ENM, Lang'at-Thoruwa CC, Njue WM, Orago ASS, Omar SA, Ndiege IO. Anti-plasmodial activity of some Kenyan medicinal plant extracts singly and in combination with chloroquine. Phytother Res. 2004;18(5):379-84.

28. Kariba RM. Antifungal activity of Ajuga remota. Fitoterapy. 2001;72(2):177-8

29. Mothana RA, Alsaid MS, Hasoon SS, Al-Mosaiyb NM. Al-RehailyAJ, al-Yahya MA. Antimicrobial and antioxidant activities and gas chromatography mass spectrometry (GC/MS) analysis of the essential oils of Ajuga bracteosa wall. Ex Benth. And Lavandula dentata L. growing wild in Yemen. Journal of Medicinal Plants Research. 2012;6(15):3066-71.

30. Ambreen M, Ahmad M. Phytochemical screening and antioxidant potential of selected species of Lamiaceae. Science International (Lahore). 2016;28(4): $3811-4$.

31. El-Hilaly J, Lyoussi B. Hypoglycaemic effect of the lyophilized aqueous extract of Ajuga iva in normal and Streptozotocin induced diabetic rats. J Ethnopharmacol. 2002;80(2-3):109-13.

32. Hsieh C-W, Ju-Yun Cheng J-Y, Wang T-H, Wang H-J, Ho W-J. Hypoglycaemic effects of Ajuga extract in vitro and in vivo. J Funct Foods. 2014;6:224-30.

33. Tahraoui A, El-Hilaly J, Israili ZH, Lyoussi B. Ethnopharmacological survey of plants used in the traditional treatment of hypertension and diabetes in southeastern Morocco (Errachidia province). J Ethnopharmacol. 2007;110:105-17.

34. Hamden K, Ayadi F, Jamoussi K, Masmoudi H, Elfeki A. Therapeutic effect of phytoecdysteroids rich extract from Ajuga iva on alloxan induced diabetic rats liver, kidney and pancreas. Biofactors. 2008;33(3):165-75.

35. El-Hilay J, Tahraoui A, Ismaili ZH, Lyoussi B. Acute hypoglycaemic, hypocholesterolemic and hypotriglyceridemic effects of continuous intravenous infusion of a lyophilised aqueous extract of Ajuga iva L. Schreber whole plant in streptozotocin-induced diabetic rats. Pak J Pharm Sci. 2007;20(4):261-8.

36. Khatri RS, Ahmad M, Pal G, Ashwlayan VD. Evaluation of antinociceptive activity of Ajuga bracteosa wall ex benth. International Journal of Green Pharmacy. 2013;7:73-6.

37. El-Hilaly J, Tahraoui A, Israili ZH, Lyoussi B. Hypolipidemic effects of acute and sub-chronic administration of an aqueous extract of Ajuga iva $\mathrm{L}$. whole plant in normal and diabetic rats. J Ethnopharmacol. 2006;105(3):441-8.

38. Cantrell CL, Rajab MS, Franzblau SG, Fronczek FR, Fischer NH. Antimycobacterial ergosterol-5,8-endoperoxide from Ajuga remota. Planta Med. 1999;65(8):732-4. doi:10.1055/s-1999-14053.

39. Asnake S, Teklehaymanot T, Hymete A, Erko B, Giday M. Evaluation of the antiplasmodial properties of selected plants in southern Ethiopia. BMC Complement Altern Med. 2015;15:448. doi:10.1186/s12906-015-0976-x.

40. Gitua JN, Muchiri DR, Nguyen XT. In vivo antimalarial activity of Ajuga remota water extracts against P.berghei in mice. Southeast Asian J Trop Med Public Health. 2012;43(3):545-8.

41. Kumar GPS, Arulselvan P, Kumar DS, Subramanian SP. Antidiabetic activity of fruits of Terminalia chebulaon streptozotocin induced diabetic rats. J Health Sci. 2006;52(2):283-91.

42. Miura T, Koike T, Ishida T. Antidiabetic activity of green tea (Thea sinensis $\mathrm{L}$.) in genetically type 2 diabetic mice. J Health Sci. 2005;51(6):708-10. 
43. Nagappa AN, Thakurdesai PA, Rao NV, Singh J. Antidiabetic activity of Terminalia catappa Linn fruits. J Ethnopharmacol. 2003;88(1):45-50

44. Committee on Care and Use of Laboratory Animals of the Institute of Laboratory Animal, Resources Commission on Life Sciences, National Research Council. Guide for the Care and use of Laboratory Animals. U.S. Department of Health and Human Services, Public Health Service National Institutes of Health (NIH), NIH Publication No. 86-23, Revised 1985.

45. Ragavan B, Krishnakumari S. Antidiabetic effect of $T$. arjuna bark extract in alloxan induced diabetic rats. Indian J Clin Biochem. 2006;21 (2):123-8.

46. OECD (Organization for Economic Cooperation and Development) guidelines for testing of chemicals 425. Acute Oral Toxicity-Up and Down procedure, first adoption, Octoberv2008, Paris, France (https://ntp.niehs.nih. gov/iccvam/suppdocs/feddocs/oecd/oecdtg425.pdf).

47. Burger C, Fischer DR, Cordenunzzi DA, Batschauer APD, Filho VC, Soares ARD. Acute \& sub-acute toxicity of the hydroalcoholic extract from Wedelia Paludosa (Acmela brasiliensis) (Asteraceae) in mice. J Pharm Sci. 2005;8(2): 370-3.

48. Carvalho EN, Carvalho NAS, Ferreira LM. Experimental model of induction of diabetes mellitus in rats. Acta Cir Bras. 2003;18:60-4.

49. Kamalakkanan N, Prince PSM. Hypoglycemic effect of water extracts of Aegle marmelos fruits in streptozotocin-diabetic rats. J Ethnopharmacol. 2003; 87(2-3):207-10.

50. Gidado A, Ameh DA, Atawodi SE. Effect of Nauclea latifolia leaves aqueous extracts on blood glucose levels of normal and alloxan-induced diabetic rats. Afr J Biotechnol. 2005;4(1):91-3.

51. Pari L, Venkateswaran S. Effect of an aqueous extract of Phaseolus vulgaris on the properties of tail tendon collagen of rats with streptozotocininduced diabetes. Braz J Med Biol Res. 2003;36(7):861-70.

52. Trease GE, Evans WC. Text book of Pharmacognosy. 13th ed. London: Bailiere-Tindall Ltd; 1989. p. 343-83.

53. Loomis TA, Hayes AW. Loomis's essentials of toxicology. 4th ed. San Diego, California, USA: Academic Press; 1996.

54. Muhtadi, Primarianti AU, Sujono TA. Antidiabetic Activity of Durian (Durio zibethinus Murr.) and Rambutan (Nephelium lappaceum L.) Fruit Peels in Alloxan Diabetic Rats. Procedia Food Science 2015; 3: 255-261.

55. Sharma B, Balomajumder C, Roy P. Hypoglycemic and hypolipidemic effects of flavonoid rich extract from Eugenia jambolana seeds on streptozotocin induced diabetic rats. Food Chem Toxicol. 2008;46:2376-83.

56. Manguro LOA, Wagai SO, Lemmen P. Flavonol and iridoid glycosides of Ajuga remota aerial parts. Phytochemistry. 2006;67(8):830-7.

57. Pala A, Jadona M, Katarea YK, Singoura PK, Rajakb H, Chaurasiyaa PK, Patila UK, Pawar RS. Ajuga bracteosa wall: a review on its ethnopharmacological and phytochemical studies. Der Pharmacia Sinica. 2011;2(2):1-10.

58. Cocquyt K, Cos P, Herdewijn P, Maes L, Van den Steen PE, Laekeman G. Ajuga Remota Benth.: from ethnopharmacology to phytomedical perspective in the treatment of malaria. Phytomedicine. 2011;18(14):1229-37.

\section{Submit your next manuscript to BioMed Centra and we will help you at every step:}

- We accept pre-submission inquiries

- Our selector tool helps you to find the most relevant journal

- We provide round the clock customer support

- Convenient online submission

- Thorough peer review

- Inclusion in PubMed and all major indexing services

- Maximum visibility for your research

Submit your manuscript at www.biomedcentral.com/submit

) Biomed Central 